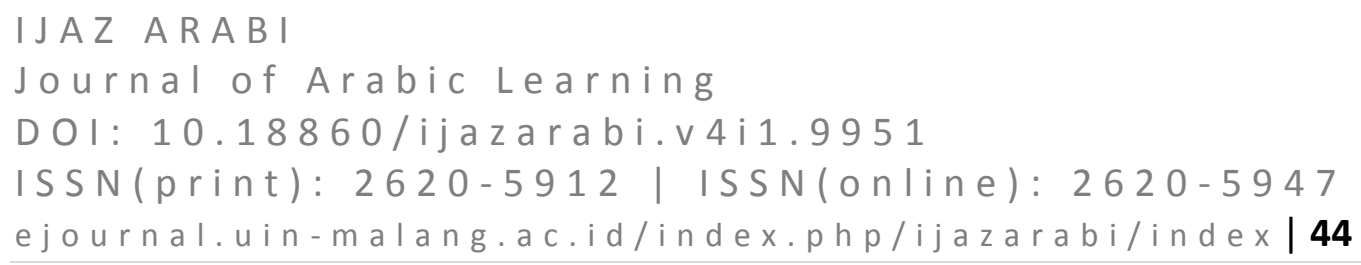

\title{
Teaching Arabic Language Base on Character Building Through Qur'an Perspective
}

\author{
Anwar Sanusi' ${ }^{1}$, Azkia Muharom Albantani ${ }^{2}$ \\ Universitas Pendidikan Indonesia, Indonesia ${ }^{1}$, Universitas Islam Negeri Syarif \\ Hidayatullah Jakarta, Indonesia ${ }^{2}$ \\ anwarsanusi@upi.edu¹ azki@uinjkt.ac.id ${ }^{2}$
}

\begin{abstract}
This study aims to reinforce character building through the Qur'an perspective during Arabic teaching and learning processes at MA Al-Musdariah 2 Cimahi, Indonesia. There are six principles of politeness in language use in Qur'an, namely; qaulan sadidan, ma'rufan, balighan, maysuran, layyinan, and kariman. The research method used in this study was phenomenology, scientific approach, and formal juridical approach. This study was classified as a descriptive qualitative study. The results of this study showed that in terms of Arabic lessons plan, they were not properly and perfectly implemented the reinforcing of politeness in language use in the light of Qur'an perspective. Whilst, in terms of teaching and learning activities including opening, core, closing and evaluating activities, they reflected several principles of politeness in language use namely; truth, honesty, fairness, kindness, being straight, smoothness, politeness, appropriateness, being respectful, solemnity, optimism, beauty, fun, logic, fluency, clearness, precision, meaningfulness, harmony, being impressive, calmness, effectiveness, gentleness, and being humble.
\end{abstract}

Keywords: Teaching Arabic; Character Building; Politeness; Qur'an Perspective

\section{INTRODUCTION}

Nowadays, value changes that often occur in education are related to the characters of young generations that are far from politeness principles identified by the increasing of moral decadence either in social life in society or in nation. Maududi (n.d., p. 3) in "ethical view point of Islam" points out that the biggest issue faced by humans from ancient times to the present is the problem of moral decadence including injustice, manipulation, deception, betrayal, hypocrisy, lies, and other crimes that are no longer committed by individuals.

In line with the aforementioned affirmations, lately, the problem of moral decadence has been rampant, epidemic, and ravaged the elements in various fields of life including education. This moral decadence is no less alarming among the students. The behaviors breaking the ethics, moral and law from the light to serious cases are often committed by the students. Further, the reinforcing of character building related to the current context is so relevant to overcome the moral crisis engulfing our nation. The moral crisis including the increasing of promiscuity, the number of children and teens abuse, crime against friends, teen-theft, cheating, 
drugs abuse, pornography, vandalism has become a social problem that has been completely solved until now. Therefore, character building is so crucial (Simarmata \& Agustina, 2017, p. 42).

The politeness in language use used by students no longer reflects as a nation's character that upholds ethical and aesthetic values. The observable manifestation of ethical and aesthetic values is politeness in language use. Alfiati (2015, p. 20) states that politeness in language use is reflected in communication procedures through verbal signs or language procedures. When communicating, speakers and the interlocutor have to pay attention to cultural norms, not just conveying ideas.

Puspidalia (2018, p. 142) states that in the activities of language use, a person needs to pay attention to the politeness aspects to minimize misunderstanding and make the interlocutor feel comfortable and calm during communicating. The use of polite language such as being gentle, polite, and respectful to the interlocutor will be regarded as a reflection of one's personality. It is in accordance with what $\operatorname{Ngalim}(2015, \mathrm{p}$. 68) states that the concept of politeness is a life necessity as well as being an essential characteristic of community life. The user of politeness in language use is not only determined by the choice of utterance, but also by other aspects that determine the level of politeness, for example age, social distance between the speaker and the interlocutor, situation, time, place, and purpose of the utterance. Thus, in terms of language use, it is necessary to pay attention to the context of language use (Jahdiah, 2018, p. 166). It is in line with what Yenni, et al, (2018, p. 41) state that a person's politeness can be seen from the actions and utterances that seems to be actualized in daily conversations/interactions. Thus, the character change becomes a measure whether the qualified education is successful of not. One tangible form of educational success is the actualization of polite students' personality.

Sauri, et al. (2018, p. 39) states that the function of education is to develop the students' potential to become better human beings. It is in accordance with what article no. 3 of regulation no. 20 year 2003 concerning the national education system states points out that "national education functions to develop capabilities and shape the dignified nation's character and civilization in order to educate the nation life, aiming at developing the students' potential to become a human being who believes and is devoted to the Almighty God, has noble character, is healthy, knowledgeable, capable, creative, independent, and becomes a democratic and responsible citizen". In addition, one of aspects that must be considered in education is the character which is the values of human behavior related to the Almighty God, self, fellow human beings, the environment, and nationality manifested in thoughts, attitudes, feelings, words, and acts based on religious, legal, ethical, custom and cultural norms (Purwaningsih, 2018, p. 129). Another aspect that must be considered is the aspect related to teachers' vision \& mission, curriculum content, syllabus, lesson plan, teaching materials, and educational facilities. Thus, it is necessary to find a form of reinforcement and improvement to overcome the 


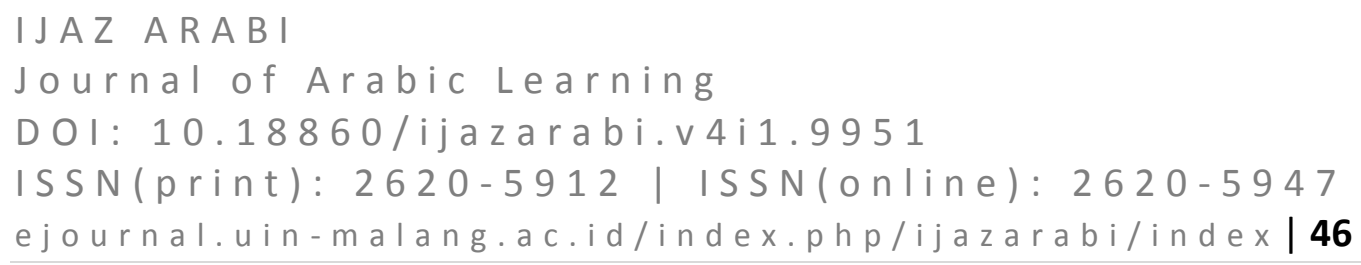

problem of character, especially the one related to the politeness of the students' language use at school (Subianto, 2013).

In the term of the actualization, in teaching and learning activities, the teachers not only get used to involve students in problems solving aiming to exercise the ability to think and teach how to solve problems, but the more essential and substantial goal is to instill understanding to students that there is something good (something beyond) through question and answer method (Rostika \& Junita, 2017; Zivitere, Riashchenko, \& Markina, 2015). During communication processes, the teachers give an example and show how to learn listening to the opinions of others, and answer with polite language as what is illustrated in the Qur'an. In this case, the teachers are positioned as 'allim (a knowledgeable person), śălih (a good and proper person), and uswah (be a role model) so that the teachers are also required to have good deeds as an actualization of his knowledge (Naim, 2013, p. 5 ). In other words, the teacher also plays a role not only as someone who influences the behavior of others but also as someone who is able to convey values, norms, and so on to students (Ngang \& Chan, 2015; Sanusi, Sauri, \& Nurbayan, 2020).

Thus, politeness in language use is an important pillar in character building that must be carried out by the teachers in order to embody nation's generations who are excellent, capable and have a noble attitude. Nevertheless, based on the interviews and observations, the Arabic teachers at MA Al-Musdariah 2 Cimahi always more prioritized cognitive knowledge than affective and psychomotor aspects in teaching and learning processes. Thus, in this case the teachers have to pay more attention to aspects of learning planning, implementation of teaching and learning activities and evaluation of the students' learning outcomes by applying the principles of polite character within it. Therefore, teaching and learning activities, from the stages of planning to evaluation, must be chosen and carried out properly so that students are able to practice the values and the principles of targeted politeness in language use.

Furthermore, the teachers' attitude throughout teaching and learning process should become an example of the implementation of polite character values for students because the teachers' role is a center and source of teaching and learning activities (Julaiha, 2014). There was a gap between what was carried out by the Arabic teachers in MA Al-Musdariah 2 Cimahi, Indonesia in the process of reinforcing the polite character actualized by the teachers, especially in composing and preparing the lesson plans. In addition, the researchers found that the reinforcing of several aspects of polite character carried out by the teachers during Arabic teaching and learning processes had not been realized properly, in which the teachers more emphasized on the reinforcing of cognitive aspects, the students only learnt the materials so that the values of polite character seems to be ignored. It could be seen from the students' behaviors namely; having less seriousness during teaching and learning processes, having no attention when the teachers conveyed the materials, joking and laughing out loud when teaching and learning processes 
IJAZ ARABI

Journal of Arabic Learning

DOI: $10.18860 / \mathrm{ijazarabi.v4i1.9951}$

ISSN(print): $2620-5912$ | ISSN(online): $2620-5947$

ejournal.uin-malang.ac.id/index.php/ijazarabi/index/47

were ongoing, swearing to their friends, having no respect for the teachers during teaching and learning processes.

\section{METHOD}

Descriptive qualitative method was used in this study. Bogdan and Taylor in Moleong (2005, p. 4) defines qualitative research as a research that produces descriptive data in the form of written or oral words from people and observable behaviors. This study aimed to understand social phenomena viewed from the perspective of the informants.

The approaches used in this research are: 1) Phenomenology defined as an approach used to uncover the facts in the field, 2) Scientific Approach understood as a research approach based on scientific disciplines, in this case, the approach is directed at the scientific competence of a researcher, or the issues under study, 3) Formal juridical approach comprehended as an approach that it is needed to provide an explanation in the research, that this research has a strong foundation referring to the Qur'an and Law of the Republic of Indonesia Number 20 Year 2003 concerning the National Education System (Depdiknas, 2003).

The researcher analyzed the ongoing Arabic teaching and learning processes through field observations by following teaching and learning processes directly. Then, the researcher conducted the interviews and documentary studies as data collections techniques to gain the required data related to reinforcing polite character. Then, the results of the data analysis would be described in detail related to teaching and learning processes to get various possibilities about the value of the character regarding politeness in language use during Arabic teaching and learning processes at MA Al-Musdariah 2 Cimahi. This study was located at Madrasah Aliyah Al-Musdariyah 2 Cimahi city, J1. Kamarung No. 25, Citeureup, North Cimahi, Cimahi City, West Java 40512.

The data sources in this study were classified into two types, namely primary data sources and secondary data sources. Primary data sources are data that researchers get directly, including: data gained from the principal who has the first idea about reinforcing the polite character, the students and the Arabic teachers who are main actors in teaching and learning processes. Then, the secondary data sources in this study are indirect data sources obtained from informants or additional data used when needed such as; student learning outcomes data, documents, and reports and other supporting elements.

\section{FINDINGS AND DISCUSSION}

\section{The Politeness And Language In Qur'an}

Al-Qur'an was revealed to humans who have the nature as creatures that require communication. Therefore, the Qur'an provides guidance for communication, especially language for humans. In communicating, Hasnan (1993) states that Islamic teachings emphasize social, religious and cultural values. In other expressions it can be said that polite language according to Islamic 
teachings is not separated from socio-cultural values and norms and religious norms as stated in the previous section. The politeness in language use in the Qur'an relates to the way of polite pronunciation, behavior and vocabulary adapted to the situation and condition (milieus) of the speaker as implied in the following verse: "Be humble you shall when you walk and soften your voice. The worst sound is the sound of a donkey. "(Surah Luqman: 19)

The above verse implies that the Qur'an encourages people to say politely in conveying their thoughts to others. Politeness is the depiction of humans who have high personalities, while impolite people are likened to animals. The Qur'an presents six principles should be used as a guide in speaking, namely:

Qaulan sadidan (Surah An-Nisa: 9 \& Surah Al-Ahzab: 70). The word 'qaulan sadidan' is revealed in the Qur'an in the context of talks about the will. Hamka (Hamka, 1983) interprets the qaulan sadidan, based on the context of the verse, is in the context of regulating the will. For this reason, the person giving the will must use clear and precise words; leaves no doubt for those who are left. Whilst, when he interprets qaulan sadidan in surah Al-Ahzab: 70 (Juz. 22: 109), it is the factual utterance that arises from a clean heart, because utterance is a depiction of what is in the heart. People who say words that can hurt others show that they have a dishonest soul. Rakhmat (1993) reveals that the meaning of qaulan sadidan in the sense of true, honest, straight, not lying, not convoluted talk. AlBuruswi (1996) points out that qaulan sadidan, in the context of utterance to orphans, that must be done in a better and loving way, such as affection for one's own children.

Based on the explanation of those experts, it could be expressed that qaulan sadidan, in terms of the context of the verse, implies the meaning of the worries of the ones who give their will to their children which are described in the form of utterances that are gentle (subtle), clear, honest, precise, proper, and fair. Being subtle means the way it is conveyed to describe the affection expressed using subtle words. It obviously contains the meaning of clearness so that there is no other interpretations. Being honest means to be transparent, there is nothing to hide. Being precise means being accurate, in accordance with the objectives to be achieved, and also in accordance with the circumstances. Being proper means it is in accordance with values, both the moral values of society and the divine stuff. While being fair means the content of the conversation is in accordance with its necessity, it is not biased or impartial.

Qaulan Ma'rufan is mentioned in the Qur'an in four Surahs (Surah AnNisa: 5, Surah Al-Baqarah: 235, Surah An-Nisa: 5 and 8, \& Surah Al-Mu ' minun: 32). Literally, the meaning of ma'ruf is good and accepted by the values prevailing in society (Shihab, 1999). Good and proper utterances are utterances that are accepted as good in the perspective of the speakers' community. Amin (1987) points out that the meaning of qaulan ma'rufan is a good and proper utterances. Being good means it is in accordance with norms and values, while being proper means it is in accordance with the background and status of the person who uttered 
it. When viewed from the context of the verse, the Qur'an uses the sentence in the context of the proposal, giving of will and inheritance. Therefore ma'rufan qaulan implies subtle utterances as utterances favored by women and children; being proper to be uttered by the speakers and the interlocutors. Hamka (1983) defines qaulan ma'rufa as polite, refined, respectful language. Then, he adds that qaulan ma'rufan in Surah Al-Isra: 23, in the context of talking to parents, it is interpreted a solemn utterance, the basis of understanding to parents. Meanwhile, when he interprets the sentence in Surah Al-Ahzab: 32 (Juz 22:24), he interprets it as proper words. Ashiddiqi (1977) calls it as good words meaning that the words that will not make others or themselves feel ashamed.

Thus, it could be concluded that qaulan ma'rufa means good words/utterances, which are polite, subtle, good, beautiful, factual, respectful, and pleasing utterances, and in accordance with the rules of law and logic. In the understanding, it implies that good utterances are being good in terms of meaning, and the language used that is language that can be understood by the interlocutors and uttered in an appropriate and a proper ways that is in accordance with the norms and addressed to the right interlocutors.

Qaulan Balighan (Surah An-Nisa: 63). Qaulan balighan is defined as a conversation that is fluent, clear, and clear in its meaning, and precisely expresses what it wants. Hamka (1983) states that the meaning of qaulan balighan is an utterance that reaches the bottom of the interlocutors' heart that is the words that are fashahat and balaghat (fluent and precise); words that leave an imprint in heartstrings. Those such words, of course, are words that come out from the heart of the person who says it.

Whilst, Alburuswi (1996) defines qaulan balighan, in terms of how to express it, as the utterances that touch and affect the heart of the interlocutors. Touching the heart means that the way how the utterances are conveyed and the content of the utterances are completely understood by the interlocutors. Whilst, the affecting the heart means that the utterances give influences and change the interlocutors' behaviors. Furthermore, Almaraghi (1943) attributes the qaulan balighan to the meaning of tabligh as one of the characteristics of the Prophet (tabligh and baligh derived from the same root word - balagha), that is the Prophet Muhammad, PBUH, assigned to deliver the warnings for his people with words that touched their hearts. Moreover, Katsir (Katsir, 1988) states that the meaning of the sentence is to advise with a touching phrase so that they quit to commit wrong deeds they have been doing.

Then, Ashiddiqi (1977) interprets qaulan balighan, in terms of the style of its disclosure, as the words/utterances that make others impressed or impress the interlocutors. Whilst, Rachmat (1993) interprets it, viewed from the communication perspective, as an eloquent utterance, a clear meaning, and calm utterance that precisely expressing what is desired. Therefore, qaulan balighan is defined as an effective communication. The effectiveness of this communication occurs when the communicator adjusts the conversation in order to be appropriate with the 
characteristics of the audience whom the speakers faces. Qaulan balighan also means that communicators touch their audiences on their hearts and brains at the same time so that communication can occur precisely or effectively. Based on the explanations of those several experts, it could be said that qaulan balighan might be interpreted as a true utterance, in terms of words. Whilst, if viewed form its target or scope, it could be interpreted as an effective utterance.

Qaulan Maysuran (Surah Al-Israa: 28). Literally, qaulan maysuran means the easy words. Almaraghi (1943) interprets it, in the context of this verse, as a soft and good utterance or a promise that does not disappoint. Considering the situation and conditions when this verse was revealed (asbab nuzul), As narrated by Saad bin Mansur who stated that when people from Muzainah asking the Prrphet Muhammad, PBUH, to be given a vehicle to go to battlefield fi sabilillah, The Prophet answered, "I don't get vehicles for you anymore." Then, they turned in tears in their sad eyes and thought that the Prophet Muhammad, PBUH, was angry with them. Hence, this verse is revealed as a hint to the Prophet in refusing a request using gentle words.

Katsir (1988) states that the meaning of qaulan maysuran with the appropriate utterance, is such pleasant promises, such as when saying, "If I get good fortune from God (Allah), I will deliver it to your house." Considering the context of the verse, Qaysulan Maysuran could be interpreted as an utterance that makes people hope and does not disappoint others. It could also be understood that qaulan maysuran is a good word/utterance containing hope for ease so that it does not make others disappointed or discouraged. Then, At-Tabari (1988) states that it could add such a beautiful and suggestive meaning. Whilst, Hamka (1983) defines qaulan maysuran as an utterance that is pleasant, good, subtle, generous, and willing to help people.

Based on the preceding explanation, qaulan maysuran, both in terms of asbab nuzul, linkages of text, and context, could be comprehended as the utterances that make others feel easy, soft, beautiful, pleasant, smooth, subtle, good, and give optimism to the interlocutors. Easy utterance means using communicative language so that it can be understood and contains words that encourage others to hope. A soft utterance is an utterance that uses expressions and is properly or appropriately uttered. Then, a subtle utterance means a kind and soft utterance so that it doesn't make others disappointed or offended. Thus, qaulan maysuran provides details procedures how to utter and use language politely.

Qaulan Layyinan (Surah Thaahaa: 44). Qaulan layyinan, in terms of literal meaning, means subtle or soft utterances. Uttering layyinan means to utter softly and subtly. 'Subtle and soft' implies a strategic meaning as revealed by Almaraghi, (1943) stating that this verse talks in the context of the Prophet Moses' conversation when confronting Pharaoh. God (Allah) taught prophet Mose to speak softly and subtly so that Pharaoh was interested and touched in his heart, so that he could receive his da'wah properly. Katsir (1988) refers to qaulan layyina as subtle and soft words/utterances. Further, Ashiddiqi (1977) interprets qaulan layyinan as 
subtle and soft utterances containing hope to persuade interlocutors remembering their obligations or to be afraid to ignore their obligations. At-Tabari (1988, p. 169) adds a kind and gentle meaning to the word layyinan.

Thus, the meaning of the phrase qaulan layyinan is a kind utterance/word subtly and softly uttered so that it can touch the heart of the person whom we talk to. Subtle and soft utterances begins with the encouragement and mood of the person who is uttering. When he utters with a sincere heart and views the person he is talking to as a brother he loves, then a soft-uttered words will be emerged.

The impact of its softness and subtlety will deliver the contents of the conversation to the interlocutors' heart. Communication occurred is a relationship of two hearts that would have an impact on the perceived content of the utterances to the interlocutors. As a result, those utterances would have a profound effect, not just on the delivered information, but also on the changes of interlocutors' views, attitudes, and behavior.

Qaulan Kariman (Surah Al-Isra: 23). In terms of the language, Qaulan Kariman means noble words/utterances. Noble words are words that give appreciation and respect to the person whom the one talks to. Almaraghi (1943) interprets qaulan kariman by referring to Ibn Musyayyab's statement that the noble words are like the words of a guilty slave before his fierce employer. tepolite followed by manners, respect, and exaltation. Thus, it could be concluded that qaulan kariman has noble understanding, respect, admiration, and appreciation. The utterances/words which has qaulan kariman meaning could be defined as subtle and soft utterances/words containing glorification, appreciation, admiration, and respect for the interlocutors. On the contrary, insulting and degrading remarks from others are identified as something impolite.

The above six principles of communication, based on the analysis of the experts, imply that the Qur'an leads and guide people to speak politely. The characteristics of polite language according to the six principles above are words/utterances that have values of: (1) truth, (2) honesty, (3) justice, (4) kindness, (5) being straight, (6) being smooth, (7) being polite, (8) appropriateness, (9) appreciation, (10) solemn, (11) optimism, (12) being beautiful (13) being pleasant, (14) logic, (15) fluency, (16) clearness, (17) being proper, ( 18) meaningful, (19) harmony, (20) being impressive, (21) calmness, (22) effectiveness, (23) softness and subtlety, (24) generosity, (25) gentleness, and (26) being humble.

Along with those principles of communication, the issue of polite language is closely related to the maxim. In this case, Sauri (2017, p. 86) compares Leech' maxims with the principles of the Qur'an and Hadith. Leech classifies maxims of politeness in language use into seven categories, namely; tact maxim, generosity maxim, approbation maxim, modesty maxim, agreement maxim, sympathy maxim and relevance maxim. Those seven maxims are based on the values that develop in society. Social values and norms are the basic rules agreed upon by the addressed society as the standard values. Then, the principles of the Qur'an and Hadith are revealed as guidance coming from Allah which can then be translated operationally 


\section{IJAZ ARABI}

Journal of Arabic Learning

DOI: $10.18860 / \mathrm{ijazarabi.v4i1.9951}$

ISSN(print): $2620-5912$ | ISSN(online): $2620-5947$

ejournal.uin-malang.ac.id/index.php/ijazarabi/index/ 52

so that they become standard values. The difference between both of them lies in the source of the values used as a reference (Ully \& Kelib, 2012). Leech takes the standard values of society, while the second one takes the standard values from the Qur'an and the Hadith. The social values will change from time to time in accordance with the dynamics of the society, while the divine values are permanent, although the changes at the operational stage, but those changes are not substantial (Marius, 2006). The following is the comparison of politeness in language use between Leech's maxims and the politeness principles in the Qur'an and Hadith

Table 1. The Comparison Of Politeness In Language

\begin{tabular}{cc} 
Leech's maxims & $\begin{array}{c}\text { Politeness principles in the Qur'an and } \\
\text { Hadith }\end{array}$ \\
\hline tact maxim & Truth \\
\hline generosity maxim & Honesty \\
\hline approbation maxim & Fairness \\
\hline Modesty maxim & Goodness \\
\hline agreement maxim & Gentleness \\
\hline Sympathy maxim & Honor \\
\hline Relevance maxim & Appropriateness \\
\hline- & Clearness \\
\hline- & Generosity \\
\hline- & Carefulness \\
\hline- & Meaningfulness \\
\hline
\end{tabular}

\section{Reinforcing Character Through Arabic Teaching and Learning}

There are several influencing factors of student learning outcomes in learning Arabic. The teachers and the way how to teach could be seen as one of factors determining the success of teaching and learning Arabic in schools. Therefore, according to Paschal \& Mkulu (2020) that teachers must have good relationships with students. In order to achieve the objectives of teaching and learning, a teacher has to have such competencies to support in achieving those objectives. It is in line with what Novauli (2015, p. 46) states that professional teachers should have such competences in conducting teaching and learning programs. Thus, teacher' competencies are one of the factors that influence whether teaching and learning objective can be achieved or not.

One of the competencies that must be possessed by teachers is the skill to strengthen student character. The teachers, in teaching and learning process, should be able to understand their students, it could be done by reinforcing the students' character building. Usman (2010, p. 80) argues that reinforcement is all forms of verbal or nonverbal responses as a feedback given dealing with students' behaviors. Then, character building is a system of inculcating character values to school members including components of knowledge, awareness or willingness and actions to implement these values (Purwaningsih, 2018, p. 129). Futhermore, 
according to Amini et al. (2017, p. 298) character building is an effort to help the development of the soul of children/learners both inward and inward to a better human.

In Arabic teaching and learning activities, reinforcing character through politeness in language use is the most fundamental issue because politeness in language use showed by the students becomes a barometer of teachers' success in teaching. Therefore, the teachers are required to reinforce the students' polite character by instilling the values of polite characters through planning, implementation, and evaluation in learning.

\section{Reinforcing The Value of Politeness in Arabic Teaching and Learning}

Before conducting teaching and learning process, the teacher should first make a plan regarding teaching and learning activities that will be conducted. It is in accordance with what Sanjaya (2015, pp. 28-29) explains that teaching and learning planning is a decision making process of the result of rationally thinking about specific learning goals and objectives, namely behavioral change and a series of activities that must be carried out as an effort to achieve those goals and objectives by utilizing all the existing potentials and sources of learning. The final result of the decision making process was the compilation of documents containing the above matters, so that the documents could then be used as a reference and guide in conducting teaching and learning processes.

Rusydie (2012, p. 14) states that as a professional teacher who has expertise in educating must have and understand the vision and mission of education. Thus, considering those visions and missions, a teacher could make priorities and worked properly. It means that a teacher must understand that teaching is not only a routine and attendance in the classroom. Furthermore, the Arabic teacher's responsibility was to develop an Arabic learning curriculum, meaning that teachers are required to always look for new ideas, improve educational practices, especially in teaching Arabic. It is in line with what Mudlofir (2012, p. 64) states that the curriculum is a plan or program and teaching is the implementation.

Teaching and learning planning was also designed in the form of syllabus and lesson plans that refer to the standard contents. Teaching and learning planning included lesson plans and the preparation of media and teaching \& learning resources, learning assessment tools, and learning scenarios. Composing syllabus and lesson plans was adjusted to the teaching and learning approach used. In fact, based on the interviews, observations and documentation studies, the researcher found that content related to the values of politeness in language use in the planning of Arabic teaching and learning conducted by the teacher had not been properly and perfectly implemented.

Thus, to achieve the goal of reinforcing the value of polite character to the students in learning Arabic, the teacher must be able to make a good lesson plan that is in accordance with the values of politeness in language use as envisioned in the Qur'an. In fact, teachers in planning Arabic teaching and learning activities 
IJAZ ARAB I

Journal of Arabic Learning

DOI: $10.18860 / \mathrm{ijazarabi.v4i1.9951}$

ISSN(print): $2620-5912$ | ISSN(online): $2620-5947$

ejournal.uin-malang.ac.id/index.php/ijazarabi/index/54

cannot be separated from: 1) Teacher's vision and mission, 2) curriculum, 3) Syllabus, 4) lesson plan 5) textbooks used by Arabic teachers.

\section{Reinforcing Politeness in The Implementation of Arabic Language Learning Opening Activities}

The initial activities or known as pre-instructional activities were conditioning the learning activities aiming to make students actively participate so that the teaching and learning process become conducive. Several activities conducted by teachers in opening were including: greetings, checking the attendance of students, giving apperception, conducting pre-test, and giving motivation. Based on the results of observation during teaching and learning process, the values of politeness in language use that could be instilled into students through preliminary activities, namely; truth, solemnity, politeness, honesty, optimism, goodness, precision, logic.

Reinforcing the value of politeness in language use in the opening activities was by preparing the situation and conditions (the value of goodness) in which the teacher greeted and prayed (truth, goodness, solemnity, and courtesy), the teacher checked the students attendance list (truth and honesty values), the teacher delivered the theme and learning objectives (logical value, precision, and optimism), the teacher made an apperception and conducted pre-test (truth value, precision, and logical), and the teacher gave initial motivation to students by giving encouragement to students to actively study (the value of optimism, goodness, and truth ).

\section{Core Activities}

Core activities in teaching and learning activities could be seen as a process of shaping students' experiences and abilities that was programmed and carried out within a certain time duration. The implementation of core activities was viewed as a learning process to achieve basic competencies which is carried out interactively, inspiring, fun, challenging, motivating students to actively participate, and provides sufficient space for initiative, creativity, and independence based on their talents, interests and development physical as well as the students' psychology. Furthermore, these core activities emphasized on the process of forming students' learning experiences in certain material or subject, which were arranged and planned by the teacher based on the applicable curriculum.

In addition, in the core activities teachers used teaching and learning methods based on the characteristics of students and subjects. Reinforcing the value of polite character that was instilled through the activities of explaining the materials (the value of truth, logic, calmness, effectiveness, humbleness, meaningfulness, clearness, precision, politeness, appropriateness, and fun), involving the students to look for extensive information about the materials given (harmonious value, truth, solemn, and being impressive), conducting interactions between teachers and students ( the value of politeness, gentleness and solemn), 
providing a chance for the students to interact with learning environments and materials (impressive and fun values, and beautify), providing a chance for the student to learn more (the value of optimism, effectiveness, and kindness), familiarizing the students to read and write by giving them assignments (goodness, optimism, precision, effectiveness), giving students the opportunity to think, analyze and solve problems and act without fear (optimism, precision, and calmness), providing a chance for the students to compete properly (values of appreciation, impressiveness, and being humble), giving the students motivation (values of optimism, kindness, meaningfulness, gentleness, and being impressive).

\section{Closing Activities}

The closing activity could not only be interpreted as an activity to close the lesson, but also as an activity to evaluate students learning outcomes and to followup. Follow-up activities had be pursued based on the process and student learning outcomes. Reinforcing of polite character values at the end of the activity was the way the teachers conclude the lesson that has been conducted (the values of clearness, being harmonious, precision, fluency, and logic). Then the teacher evaluated at the end of lesson (the value of being straight, appropriateness, and appreciation), gave motivation to the students (the value of optimism, kindness, impressiveness, and meaningfulness) prayed and ended up the lesson by saying greeting (truth, goodness, respectfulness, and politeness).

\section{Reinforcing Politeness Through Evaluation In Arabic Teaching and Learning}

Evaluation is the most important part of teaching and learning activities conducted by a teacher to determine the level of initial knowledge, students' skills and teaching programs. Evaluation could be conducted at the beginning of the lesson in order to find out how far the level of students' knowledge and at the end of the semester in the form of the final exam to know the description of the students 'perceived ability regarding the materials given and conveyed. The evaluation carried out was useful to see changes in skills in terms of the level of knowledge, ability, skills and changes in attitude in a learning unit or in a learning program that has been conducted. Therefore, teachers are required to be proficient in learning evaluation.

Learning evaluation activities related to the value of politeness in language use in Arabic learning at MA Al-Musdariah 2 Cimahi was inseparable from the evaluation at the end of the teaching and learning activities carried out by the teachers (the values of honesty, truth, and appreciation). The teachers then provided motivation to the students they know they know the score of their final exam (the value of optimism, kindness, being impressive, and meaningfulness).

\section{CONCLUSION}

Based on the analysis and discussion, it showed that the reinforcing of politeness in language use in the light of the Qur'an perspective in planning stage 
of Arabic teaching and learning at MA Al-Musdariyah 2 Cimahi was not properly and perfectly actualized, then the reinforcing of politeness in language use in the light of the Qur'an perspective in the implementation of Arabic teaching and learning consisting of opening, core, closing and evaluating activities was actualized the values politeness in language use namely; truth, honesty, fairness, goodness, being straight, subtlety, politeness, appropriateness, appreciation, solemnity, optimism, beautify, being pleasant, logic, fluency, clearness, precision, meaningfulness, being harmonious, being impressive, calmness, effectiveness, gentleness, and being humble.

Reinforcing the character building through politeness in the Qur'an perspective should be properly integrated in planning, implementing and evaluating teaching and learning processes. The outcomes of the reinforcing of politeness in language use in the light of Qur'an perspective through Arabic teaching and learning was the students who had competencies academically and had wellmannered. Another thing that was so essential in providing positive feedback and reinforcement was informing the results of students' exam, especially regarding the wrong and the correct answers, and giving a chance for the students to revise their wrong answers and giving reward for the students who pass the exam in order to make them more active.

\section{REFERENCES}

Al-Buruswi, I. H. (1996). Terjemahan Tafsir Ruhul Bayan Juz 5. Bandung: CV Diponegoro.

Alfiati, A. (2015). Santun Berbahasa Indonesia. An-Nuha, 2(1), 18-34.

Al-Maraghi, M. (1943). Tafsir Al-Maraghi. Beirut: Dar el Fikr.

Al-Maududi, S. A. A. (n.d.). Ethical View Point of Islam. Pakistan: Islamic Publications Pvt Ltd.

Amin, M. (1987). Etika Komunikasi Masa dalam Pandangan Islam. Jakarta: Logos.

Amini, A., Yurnita, S., \& Hasnidar, H. (2017). The Development Of Character Education Model Trough An Integrated Curriculum At Elementary Education Level In Medan City. International Journal on Language, Research and Education Studies (IJLRES), 1(2).

Ashiddiqi, H. (1977). Tafsir AL-Bayan Jilid 1 dan 2. Bandung: Al-'Maarif.

At-Thabari, J. (1988). Jami'u al-Bayan an Ta'wili ayatil Qur'an juz 4, 5,15, 16, 22. Beirut: Dar el Fikr.

Depdiknas. Undang-undang RI. , Pub. L. No. 20 (2003).

Hamka, H. (1983). Tafsir Al-Azhar. Jakarta: Bulan bintang.

Hasnan, H. (1993). Komunikasi Menurut Pendekatan Islam. Audenta, 1(1).

Jahdiah, J. (2018). Kesantunan Tindak Tutur Bamamai dalam Bahasa Banjar: Berdasarkan Skala Kesantunan Leech. Jurnal Ranah, 7(2), 164-179.

Julaiha, S. (2014). Implementasi Pendidikan Karakter dalam Pembelajaran. Dinamika Ilmu, 14(2).

Katsir, I. (1410). Tafsir Ibnu Katsir. Riyadh: Maktabah Maa’arif. 


\section{IJAZ ARABI}

Journal of Arabic Learning

DOI: $10.18860 / \mathrm{ijazarabi.v4i1.9951}$

ISSN(print): 2620-5912 | ISSN(onIine): 2620-5947

ejournal.uin-malang.ac.id/index.php/ijazarabi/index/ 57

Marius, J. A. (2006). Kajian Analitik Perubahan Sosial. Jurnal Penyuluhan, 2(2).

Moleong, L., J. (2005). Metode Penelitian Kualitatif. Bandung: PT Remaja Rosdakarya.

Mudlofir, A. (2012). Pendidik Profesional: Konsep, Strategi, dan Apllikasinya dalam Peningkatan Mutu Pendidikan di Indonesia. Jakarta: Raja Grafindo Persada.

Naim, N. (2013). Menjadi Guru Inspiratif (4th ed.). Yogyakarta: Pustaka Pelajar.

Ngalim, A. (2015). Pendidikan Muhammadiyah yang Berkemajuan Berbasis Kesantunan Berbahasa (Studi Perkembangan Amaliyah Syariah Islam di Desa Karang Puluhan). Jurnal Tajdida, 13(1), 64-74.

Ngang, T. K., \& Chan, T. C. (2015). The Importance of Ethics, Moral and Professional Skills of Novice Teachers. Procedia - Social and Behavioral Sciences, 205, 8-12. doi: 10.1016/j.sbspro.2015.09.004

Novauli, M. F. (2015). Kompetensi Guru dalam Peningkatan Prestasi Belajar pada SMP Negeri dalam Kota Banda Aceh. Jurnal Administrasi Pendidikan, $3(1), 45-67$.

Paschal, M. J., \& Mkulu, D. G. (2020). Teacher-Students' Relationship and Students' AcademicPerformance in Public Secondary Schools in Magu District, Tanzania. Journal of Research in Education and Society, 11(1).

Purwaningsih, P. (2018). Internalisasi Nilai-Nilai Karakter Pada Pembelajaran Pendidikan Agama Islam (PAI) di SMP Negeri 4 Sungai Raya. JRTIE: Journal of Research and Thought of Islamic Education, 1(1), 128-140.

Puspidalia, Y. S. (2018). Eufimisme dalam Dua Novel Duka Cinta sebagai Wujud Kesantunan Berbahasa. Jurnal Kodifikasia, 12(1), 141-153.

Rakhmat, J. (1993). “Audienta” Prinsip-Prinsip Komunikasi Menurut Al-Qur'an. Jurnal Komunikasi, 1(1), 35-56.

Rostika, D., \& Junita, H. (2017). Peningkatan Kemampuan Pemecahan Masalah Siswa SD dalam Pembelajaran Matematika dengan Model Diskursus Multy Representation (DMR). EduHumaniora: Jurnal Pendidikan Dasar, 9(1).

Rusydie, S. (2012). Tuntunan Menjadi Guru Favorit (1st ed.). Jakarta: Flash Book.

Sanjaya, W. (2015). Perencanaan dan Desain Sistem Pembelajaran. Jakarta: Kencana.

Sanusi, A., Sauri, S., \& Nurbayan, Y. (2020). Non-Native Arabic Language Teacher: Low Teacher's Professional Competence Low Quality Outcomes? Arabiyat: Jurnal Pendidikan Bahasa Arab Dan Kebahasaaraban, 7(1), 45-60. doi: 10.15408/a.v7i1.12722

Sauri, S. (2017). Kesantunan Berbahasa (Kajian Nilai, Moral, Etika, Akhlak, dan Karakter). Bandung: Royyan Press.

Sauri, S. (2018). A critique of Local Wisdom Values in Indonesia's Pesantren. Pertanika J. Soc. Sci. \& Hum., 26, 37-50.

Shihab, Q. (1999). Wawasan Al-Qur'an. Bandung: Mizan. 
Journal of Arabic Learning

DOI: $10.18860 / \mathrm{ijazarabi.v4i1.9951}$

ISSN(print): 2620-5912 | ISSN(onIine): 2620-5947

ejournal.uin-malang.ac.id/index.php/ijazarabi/index/ 58

Simarmata, M. Y., \& Agustina, R. (2017). Kefektifan Bahan Ajar Berbasis Pendidikan Karakter untuk Meningkatkan Kesantunan Tindak tutur Imperatif. Jurnal Pendidikan Bahasa Dan Sastra Indonesia, 2(2), 41-43.

Subianto, J. (2013). Peran Keluarga, Sekolah, dan Masyarakat dalam Pembentukan Karakter Berkualitas. Edukasia, 8(2).

Ully, A., \& Kelib, A. (2012). Penerapan Prinsip-Prinsip Islam dalam Pengaturan Corporate Social Responsibility di Indonesia. Law Reform, 7(2).

Usman, Moh. U. (2010). Menjadi Guru Profesional. Bandung: PT. Remaja Rosdakarya.

Yenni, E. (2018). Pola Pengajaran Kesantunan Berbahasa Anak di Lingkungan Keluarga. Jurnal Tarbiyah, 25(1), 40-60.

Zivitere, M., Riashchenko, V., \& Markina, I. (2015). Teacher - Pedagogical Creativity and Developer Promoter. Procedia - Social and Behavioral Sciences, 174, 4068-4073. doi: 10.1016/j.sbspro.2015.01.1156 